\title{
Çalışanların Mesleki Tükenmişlik, Mesleki Doyum ve Yaşam Doyumunun İncelenmesi ${ }^{1}$
}

\author{
DOI: 10.26466/opus.613614
}

\author{
$*$ \\ Bünyamin Çetinkaya* - Fikret Gülaçtı** - Zeynep Çiftci*** \\ * Dr. Öğrt. Üyesi, Giresun Üniversitesi, Eğitim Fakültesi, Eğitim Bilimleri Bölümü \\ E-Posta: bumi55@gmail.com \\ ORCID: $\underline{0000-0001-8435-5885}$ \\ ** Doç. Dr. Erzincan Binali Yıldırım Üniversitesi, Eğitim Fakültesi, Eğitim Bilimleri Bölümü \\ E-Posta: fgulacti@erzincan.edu.tr ORCID: 0000-0002-3200-1994 \\ ***Öğr. Gör. Erzincan Binali Yıldırım Üniversitesi, Refahiye Sağlık Hizmetleri MYO \\ ORCID: $\underline{0000-0002-0971-8508}$
}

Öz

Bu araştırma, öğretmen, akademisyen ve diğer çalışanların mesleki doyum, tükenmişlik ve yaşam doyumu düzeylerinin bazı değişkenler tarafindan nasıl etkilendiğini incelenmek amacıyla yapılmıştır. Araştırmanın çalışma gurubunu Erzincan İli Refahiye ilçesinde bulunan MEB' e bağlı okullar, Meslek Yüksek Okulunda görev yapan akademisyenler ile devlete bă̆lı ya da özel kurumlarda çalışan diğer 128 kişiden oluşmaktadır. MEB ve akademisyen olarak katılan sayısı 64 kişi, diğer kurumlardan da 64 kişi çalışmaya katılmıştır. Araştırma ilişkisel tarama modelinde yapılmış betimsel bir çalışmadır. Araştırmada veri toplama aracı olarak Kişisel Bilgi Formu, Maslach Tükenmişlik Envanteri, Mesleki Doyum Ölçeği ve Yaşam Doyumu Ölçeği kullanılmıştır. Araştırma verileri, normallik testlerine tabi tutularak çıkan sonuçlara göre analizler yapılmıştır. Veriler Mann Whitney U Testi, Kruskal Wallis H Testi ve Anova ile analiz edilmiştir. Araştırma sonuçlarına göre, mesleki tükenmiş̧lik düzeyleri; katılımcıların kişilik özellikleri, üstlerinden takdir görme değişkenlerine göre anlaml farklılaşmakta, katılımcıların cinsiyet, meslekler, yaş, medeni durum, mesleki kıdem, algılanan sosyo-ekonomik düzeylerin göre farklılaşmamaktadır. Mesleki doyum değişkeni ele alındığında; katılıcıların cinsiyet, meslek, yaş, kişilik, üstlerden takdir görme değişkenlerine göre anlamlı olarak farklılaştığı, algılanan sosyo-ekonomik düzey, mesleki kıdem, medeni durum değişkenlerine göre farklılaşmadığı sonuçları elde edilmiştir. Yaşam doyumu düzeylerine bakıldı̆̆ında ise cinsiyet, algllanan sosyo-ekonomik düzey, üstlerinden takdir alma değiş̧kenleri ile anlaml fark oluşmakta, katılımcıların yaş, meslek, kişilik, medeni durum, mesleki kıdem değişkenlerine göre anlamlı farklılaşmanın olmadığı sonuç olarak elde edilmiştir.

Anahtar Kelimeler: Mesleki Tükenmişlik, Mesleki Doyum, Yaşam Doyumu, Öğretmen, Akademisyen

\footnotetext{
${ }^{1}$ Bu araştırma Refahiye Araştırmaları Sempozyumunda özet bildiri olarak sunulmuştur.
} 


\title{
Investigation of Occupational Burnout, Occupational Satisfaction and Life Satisfaction of Employees
}

\begin{abstract}
This research aims to investigate how teachers, academics and other employees are affected in a variety of situations in the diversity of their professional satisfaction, burnout and life satisfaction lives. The study group consisted of 128 people working in MEB 's affiliated schools, academicians working in Vocational High Schools and private institutions affiliated with the state in Erzincan Province Refahiye district. A descriptive study was conducted in the research-relational survey model of 64 people and 64 people from other institutions. Personal Information Form, Maslach Burnout Inventory, Occupational Satisfaction Scale and Life Satisfaction Scale. By conducting analyzes according to normality tests. The data were analyzed with Mann Whitney U Test, Kruskal Wallis H Test and Anova.

According to the research results, occupational burnout levels; characteristics of leaders, value forms of their superiors, differences, differences, occupations, age, marital status, professional seniority, differentiation of perceived socio-economic levels. The professional satisfaction variable can be addressed; The gender, occupation, age, personality and the superiority of the participants were differentiated according to the variables of appreciation, and at the perceived socio-economic level, differentiation rates were obtained according to the variables of vocational seniority and marital status. While there is a significant difference in terms of gender, perceived socio-economic level, and appreciation variables, there is a significant difference in terms of age, occupation, personality, marital status and international seniority levels.
\end{abstract}

Keywords Occupational Burnout, Occupational Satisfaction, Life Satisfaction, Teacher, Academician 


\section{Giriş}

İnsanoğlunun sanayi toplumu ile yüzleşmesi ile her işin belli bir eğitimle, belli yeteneklerle yapılması zorunluluk olarak ortaya çıkmıştır. Kuzgun (1982) mesleği, bir kimsenin belli bir eğitim yoluyla edindiği ve para kazanmak için yaptığı sonucunda bir ürün veya hizmet ortaya koyduğu, kuralları toplum tarafından belirlenmiş etkinlikler bütünü olarak tanımlamakta ve mesleğin para kazanma ve geçimi sağlama yolunun ötesinde, belki de bunun kadar önemli olarak yetenekleri kullanma ve geliştirme yolu, kendini gerçekleştirme, kendini ifade etme aracı olduğunun söylenebileceğini ifade etmektedir. Hobi ile mesleği ayırt eden önemli faktörlerden biri hobinin sonunda elde edilen ürünlerin zevk alarak ve topluma zarar vermediği sürece bu faaliyetleri düzenleyen bir kuralın olmayışıdır. Ancak mesleği yalnızca para kazanmak için yapılan etkinlik olarak tanımlamak, amacını fazla sinırlamak olur. Bireyler işleri ve meslekleri yoluyla statü, tanınma, başarma gibi gereksinimlerini doyurur ve toplumla ilişki kurarlar. Meslek ve bir işte çalışma, bireylerin benlik saygısının gelişimine de katkıda bulunmaktadır. Çalışan ve bir şey üretmek için değişik etkinliklerle uğraşan insanlar değerli olduklarını hissederler ve benlik saygıları güçlenir.

Sanayi ve modern toplumun karşılaştığı önemli kavramlardan biri de tükenmişliktir. Freudenberger (1974) tarafından mesleki bir tehlike olarak ilk klinik tanımlamalardan birini yapmıştır. Freudenberger (1974) tükenmişliği; Başarısız olma, yıpranma, enerji ve güç kaybı veya karşılanamayan istekler sonucu bireyin iç kaynaklarında tükenme durumu şeklinde ifade etmiştir (Akt. Vızlı, 2005). Günümüz alan yazında ise en yaygın kabul gören tükenmişlik tanımı Maslach Tükenmişlik Envanterini geliştiren Christina Maslach'a aittir. Maslach, tükenmişlik kavramını; duygusal tükenme (emotional exhaustion), duyarsızlaşma (depersonalization) ve kişisel başarıya (personel accomplishment) ilişkin duyguları kategorize eden üç ayrı boyutta ele almaktadır (Ergin, 1992). Başka bir deyişle Maslach ve Zimbargo'ya (1982) göre tükenmişlik “İşi gereği insanlarla yoğun bir ilişki içerisinde olanlarda görülen duygusal tükenme, duyarsızlaşma, ve düşük kişisel başarı hissi" şeklinde tanımlanmaktadır. Tükenmişlik alt faktörlerinin bulunduğu ve bunların duygusal tükenme, duyarsızlaştırma, düşük kişisel başarı duygusu olduğu ifade edilmiştir. 
Maslach, Schaufeli, Leiter, (2001) ve Wright ve Douglas'a (1997) göre duygusal tükenme; tükenmişliğin bireysel stres boyutunu belirtmekte ve bireyin duygusal ve fiziksel kaynaklarında azalmayı ifade etmektedir. Duyarsızlaşma; tükenmişliğin kişiler arası boyutunu temsil etmekte ve müşterilere yönelik negatif, katı tutumları ve işe karşı tepkisizleşmeyi belirtmektedir. Maslach, Schaufeli, Leiter, (2001), Maslach ve Zimbardo, (1982) ve Wright ve Douglas'a (1997) göre düşük kişisel başarı duygusu ise; kişinin kendisini olumsuz değerlendirme eğiliminde olmasını ifade etmektedir.

Bireyin mesleğinden aldığ 1 doyum ya da doyumsuzluk çevresindeki herkesi etkileyebilir. Çakan'a (2013) göre mesleki doyum, insanların var olan ilişkileriyle ilgili inanç ve duygularının birikimidir. Tekin, Bozkır, Sazak, ve Özer'e (2014) göre bu duygu birikimi olumlu ya da olumsuz bir şekilde pratikte, çalışma performanslarında kendini gösterir. Doyum düzeyinin düşük olması sonucunda, konsantrasyon eksikliği, hata yapma olasıllğı, sinirlilik gibi bir çok olumsuz durum kendini gösterir. Mersin (2007), mesleki doyumu, bireyin yapmakta olduğu işle ilgili kazanç, başarılı olma gibi maddi ve manevi ihtiyaçlarının giderilmesi, bu ihtiyaçlardan kaynaklanan gerginlik hallerinin sona ermesi ve belirli bir memnuniyet düzeyinin ortaya çıkması olarak ifade etmiştir.

İnsanın mutluluğu ve mutluluğunu sağlayan koşulların ne olduğu çok eski zamanlardan beri dikkati çeken bir konu olmuştur. Deiner ve Deiner'e (1995) göre yaşam doyumu bir anlamda bireyin belirlediği hedeflere ulaşma derecesidir. Deiner (1984) bireysel hedeflere ulaşma düzeyinin artmasının, yaşam doyumunu artırdığını ifade etmiştir. Olumlu duygular ve doyuma ilişkin bilişsel yargılar (Diener ve Suh, 1997; Diener ve Larsen, 1993; Gülaçtı, 2010; Yiğit, 2013; Gülaçtı, 2014) çeşitli yaşam alanlarına ilişkin olabilmekte ve bunların toplamı genel yaşam doyumunu yansıtmaktadır (Gülaçtı, 2009). Vara'ya (1999) göre yaşam doyumu; mutluluk, moral gibi değişik açılardan iyi olma halini ifade eder ve günlük ilişkiler içinde olumlu duygunun olumsuz duyguya karşın baskın olmasıdır (Akt. Özer ve Karabulut, 2003)

$\mathrm{Bu}$ araştırmanın amacı öğretmen, akademisyen ve diğer çalışanların mesleki doyum, tükenmişlik ve yaşam doyumu düzeylerinin bazı değişkenler tarafından nasıl etkilendiğinin belirlenebilmesidir. 


\section{Yöntem}

Araştırmada örnekleme tekniklerinden, küme örnekleme tekniği (oransız küme örnekleme) kullanılmıştır. Bu tekniğe göre, evrenden seçilecek kümeler üzerinde araştırma yapılabilir. Küme örnekleme tekniği evrendeki bütün kümelerin tek tek (bütün elemanlarıyla birlikte) eşit seçilme şansına sahip oldukları örnekleme tekniğidir (Karasar, 1995:114-115). Veri toplama aracı olarak, araştırmacılar tarafından araştırmanın amacı doğrultusunda hazırlanmış olan bir Kişisel Bilgi Formu, Maslach Tükenmişlik Envanteri, Mesleki Doyum Ölçeği ve Yaşam Doyumu Ölçeği kullanılmıştır.

\section{Veri Toplama Araçları}

Kişisel Bilgi Formu; Bu formda araştırmacılar tarafından geliştirilen ve çalışanların bazı sosyo-demografik özelliklerini (cinsiyet, yaş, medeni durum, çocuk sahibi olma durumu, kıdem durumu algıladıkları ekonomik durum düzeyleri, algilanan mesleki uyum düzeyi, üstlerden takdir alma sıklığı) betimlemeye ilişkin sorular yer almaktadır.

Mesleki Doyum Ölçeği: Çalışanların mesleki doyumlarını belirlemek amacıyla Likert yöntemi ile geliştirilmiş olan 20 önermeden oluşan "Mesleki Doyum Ölçeği" kullanılmıştır. Kuzgun, Aydemir-Sevim ve Hamamcı (1998) tarafından geliştirilen "Mesleki Doyum Ölçeği" beşli dereceli Likert tipinde olup 20 maddeden oluşmaktadır. Bunlar 13 maddeden oluşan “ niteliğe uygunluk" ve 7 maddeden oluşan " gelişme fırsatı (isteği)" alt ölçekleridir. Ölçeğin Cronbach Alfa formülü ile belirlenen iç tutarlılık katsayısın.90'dır. Bu katsayı birinci alt ölçek için .91, ikinci alt ölçek için .75 olarak bulunmuştur. Ölçekten alınabilecek en düşük puan 20, en yüksek puan 100'dür. Ölçekten alınan yüksek puan, mesleki doyumun yüksekliğini işaret etmektedir. Mesleki doyum ölçeğinin geçerliliği, iki faktörün açıkladıkları toplam varyans $\% 48,6$ 'dır. Birinci faktör toplam varyansın \%36,4'ünü açıkladığ1 için ölçeğin tek boyutlu olarak da kullanılabilmesi düşünülmüştür (Kuzgun, Aydemir-Sevim ve Hamamc1, 2012, s.80-81) .

Yaşam Doyumu Ölçeği; Araştırmada, Diener ve arkadaşları tarafından 1985 yılında geliştirilen YDÖ - The Satisfaction with Life Scale (SWLS) 
kullanılmıştır. Köker (1991) tarafından Türkçeye çevrilip adapte edilmiştir. Yaşam Doyumu Ölçeği, bireylerin yaşamlarından aldıkları doyumu belirlemek amacıyla geliştirilmiştir. Ölçek, likert tarzı 7 dereceli (1: kesinlikle katılmıyorum - 7: Kesinlikle katılıyorum) 5 maddeden oluşmaktadır. Yaşam doyumu ölçeğinden alınabilecek en yüksek puan 35, en düşük puan ise 5 'tir. Ölçekten alınan puanın düşük olması yaşam doyumunun düşük olduğunun göstergesi olarak kabul edilmektedir

Maslach Tükenmişlik Envanteri: Ölçek Maslach ve Jackson (1981), tarafından geliştirilmiştir. Ergin (1992), tarafından Türkçe'ye çevrilen envanterin 235 kişilik (doktor, hemşire, öğretmen, avukat, polis vb.) bir grupla ön denemesi yapılmış, bu gruptan elde edilen verilerin analizi sonucunda envanterde bazı değişiklikler yapılmıştır. Özgün formu "hiçbir zaman, yılda birkaç kere, ayda bir, ayda birkaç kere, haftada bir, haftada birkaç kere, her gün" şeklinde 7 basamaklı cevap seçeneklerinden oluşmaktadır. Türkçe uyarlaması ise "hiçbir zaman, çok nadir, bazen, çoğu zaman, her zaman" şeklinde 5 basamaklı cevap seçeneklerinden oluşmaktadır.

Duygusal Tükenme: (Emotional Exhaustion) alt ölçeği, kişinin mesleği ya da işi tarafından tüketilmiş ve aşırı yüklenilmiş olma duygularını tanımlar. Duyarsızlaşma: (Deporsonalization) alt ölçeği, kişinin hizmet verdiklerine karşı, bireylerin kendilerine özgü birer varlık olduklarını dikkate almaksızın duygudan yoksun biçimde davranmalarını tanımlar. Kişisel Başarı: (Personal Accomplishment) kişisel başarı alt ölçeği, insanlarla çalışan bir kimsede yeterlilik ve başarıyla üstesinden gelme duygularını tanımlar.

Ölçeğin güvenilirliği ve geçerliği: Ölçeğin güvenilirlik ve geçerlik çalışmaları Ergin (1992), ve Çam (1992), tarafından yapılmıştır. 552 doktor ve hemşireden elde edilen verilerin üç alt boyuta ilişkin Cronbach alfa kat sayıları Duygusal Tükenme .83, Duyarsızlaşma.65, Kişisel Başarı .72'dir. Ölçeğin alt boyutlarına ilişkin tekrar test tekrar güvenirlik kat sayıları ise Duygusal Tükenme.83, Duyarsızlaşma .72, Kişisel Başarı .67'dir. Çam (1992), yapmış olduğu güvenirlik çalışmasında Duygusal Tükenme .89, Duyarsızlaşma .71, Kişisel Başarı .72 olarak bulmuştur. 


\section{Verilerin Analizi}

Araştırmanın sorularına cevap verebilmek için kullanılan değişkenlerin yapısına ve verilerin özelliklerine uygun olacak şekilde parametrik ve parametrik olmayan istatistiksel yöntemlerden faydalanılmıştır. Mesleki doyum, mesleki tükenmişlik, yaşam doyumu ölçeklerinden alınan puan sürekli değişkendir ve araştırmanın bağımlı değişkeni olarak ele alınmıştır. Bağımlı değişkenin evrendeki dağılımının normal olduğu kabul edilmektedir. Araştırmanın bağımsız değişkenini ise bireylerin sosyo-demografik özellikleri oluşturmaktadır. Araştırma verileri, normallik testlerine tabi tutularak çıkan sonuçlara göre analizler yapılmıştır. Veriler Mann Whitney U Testi, Kruskal Wallis H Testi ve Anova ile analiz edilmiştir. Araştırmanın veri analizi kısmında SPSS 22.0 İstatistiksel analiz programı kullanılmıştır.

\section{Çalışma Grubu}

Araştırmanın çalışma gurubunu Erzincan İli Refahiye ilçesinde bulunan MEB' e bağlı okullar, Meslek Yüksek Okulunda görev yapan akademisyenler ile devlete bağlı ya da özel kurumlarda çalışan diğer 128 kişiye gönüllülük esasına göre araştırmacılar tarafından ulaşılmış ve örnekleme alınmıştır. MEB ve akademisyen olarak katılan sayısı 64 kişi, diğer kurumlardan da 64 kişi çalışmaya katılmıştır. Çalışma grubundaki katılımcıların araştırmaya konu olan bazı özelliklerinin dağılımları, tekrar yapmaktan kaçınmak için aşağıdaki tabloda ayrıntılı olarak verilmiştir

Tablo Katılımcıların demografik özelliklerine göre dă̆ılımı

\begin{tabular}{lll}
\hline Cinsiyet & $\mathbf{N}$ & $\%$ \\
\hline Kadın & 40 & 31,3 \\
\hline Erkek & 88 & 68,8 \\
\hline Meslek & & \\
\hline Ö̈̆retmen & 64 & 50,0 \\
\hline Diğer & 64 & 50,0 \\
\hline Yaş & & \\
\hline 25 tenküçük & 12 & 9,4 \\
\hline $26-35$ & 63 & 49,2 \\
\hline $36-45$ & 31 & 24,2 \\
\hline $46-55$ & 15 & 11,7 \\
\hline 56 ve üzeri & 7 & 5,5
\end{tabular}




\begin{tabular}{|c|c|c|}
\hline \multicolumn{3}{|l|}{ Medeni durum } \\
\hline Evli & 85 & 66,4 \\
\hline Bekar & 39 & 30,5 \\
\hline Boşanmış & 4 & 3,1 \\
\hline \multicolumn{3}{|l|}{ Mesleki kıdem } \\
\hline $0-2$ & 28 & 21,9 \\
\hline $3-5$ & 35 & 27,3 \\
\hline $6-10$ & 29 & 22,7 \\
\hline $11-15$ & 8 & 6,3 \\
\hline $16-20$ & 9 & 7,0 \\
\hline 21 ve üstü & 19 & 14,8 \\
\hline \multicolumn{3}{|c|}{ Algılanan sosyo-ekonomik } \\
\hline Üst & 5 & 3,9 \\
\hline Orta & 109 & 85,2 \\
\hline Alt & 14 & 10,9 \\
\hline \multicolumn{3}{|c|}{ Kişisel olarak mesleğe uygunluk } \\
\hline Çok uygun & 37 & 28,9 \\
\hline Kismen uygun & 32 & 25,0 \\
\hline Uygun & 59 & 46,1 \\
\hline \multicolumn{3}{|c|}{ Mesleki takdir görme } \\
\hline Her zaman & 13 & 10,2 \\
\hline Siklikla & 25 & 19,5 \\
\hline Bazen & 66 & 51,6 \\
\hline Nadiren & 14 & 10,9 \\
\hline Hiçbir zaman & 10 & 7,8 \\
\hline
\end{tabular}

\section{Bulgular}

Tablo 1. Çalışanların Cinsiyeti ile Yaşam doyumu, Mesleki doyum ve Tükenmişlik Alt Boyutları puanlarına göre Mann Whitney U Testi Sonuçları

\begin{tabular}{lllllll}
\hline & $\begin{array}{l}\text { Cinsi- } \\
\text { yet }\end{array}$ & N & Sıra Ortalaması & $\begin{array}{l}\text { Sira } \\
\text { lam }\end{array}$ & Top- & U \\
\hline Duyusal Tükenme & Kadın & 40 & 59,91 & 2396,50 & 1576.50 & .345 \\
& Erkek & 88 & 66,59 & 5859,50 & & \\
\hline Duyarsızlaşma & Kadın & 40 & 64,35 & 2574,00 & 1754.00 & .975 \\
& Erkek & 88 & 64,57 & 5682,00 & & \\
\hline Kişisel Başarı & Kadın & 40 & 68,68 & 2747,00 & 1593.00 & .389 \\
& Erkek & 88 & 62,60 & 5509,00 & & \\
\hline Mesleki Doyun & Kadın & 40 & 78,33 & 3133,00 & 1207.00 & .004 \\
& Erkek & 88 & 58,22 & 5123,00 & & \\
\hline Yaşam doyumu & Kadın & 40 & 77,69 & 3107,50 & 1232.50 & .007 \\
& Erkek & 88 & 58,51 & 5148,50 & & \\
\hline
\end{tabular}


Tablo 1'de çalışanların Mesleki doyum puanları ve Yaşam doyumu puanları cinsiyet değişkenine göre anlamlı şekilde farklılaşmaktadır ( $\mathrm{p}<.05)$. İkisinde de kadın çalışanların ortalaması erkeklerin ortalamasından fazlayken Mesleki tükenmiştik tüm alt boyutları cinsiyet değişkenine göre anlamlı şekilde farklılaşmamaktadır ( $>$ >.05)

Tablo 2. Çalışanların Meslekleri ile Yaşam doyumu, Mesleki doyum ve Tükenmişlik Alt Boyutları puanlarna göre Mann Whitney U Testi Sonuçları

\begin{tabular}{|c|c|c|c|c|c|c|c|}
\hline & Cinsiyet & $\mathbf{N}$ & $\begin{array}{l}\text { Sira } \\
\text { masi }\end{array}$ & Ortala- & $\begin{array}{ll}\text { Sira } & \text { Top- } \\
\text { lam } & \\
\end{array}$ & $\mathrm{U}$ & $\mathrm{p}$ \\
\hline \multirow[t]{2}{*}{ Duyusal Tükenme } & Öğretmen & 64 & 59,76 & & 3824,50 & 1744,500 & .147 \\
\hline & Diğer & 64 & 69,24 & & 4431,50 & & \\
\hline \multirow[t]{2}{*}{ Duyarsızlaşma } & Öğretmen & 64 & 61,95 & & 3965,00 & 1885.00 & .435 \\
\hline & Diğer & 64 & 67,05 & & 4291,00 & & \\
\hline \multirow[t]{2}{*}{ Kişisel Başarı } & Öğretmen & 64 & 67,39 & & 4313,00 & 1863.00 & .376 \\
\hline & Diğer & 64 & 61,61 & & 3943,00 & & \\
\hline \multirow[t]{2}{*}{ Mesleki Doyun } & Öğretmen & 64 & 73,96 & & 4733,50 & 1442.50 & .004 \\
\hline & Diğer & 64 & 55,04 & & 3522,50 & & \\
\hline \multirow[t]{2}{*}{ Yaşam doyumu } & Öğretmen & 64 & 68,63 & & 4392,50 & 1783.50 & .207 \\
\hline & Diğer & 64 & 60,37 & & 3863,50 & & \\
\hline
\end{tabular}

Tablo 2'de çalışanların Mesleki doyum puanları meslek değişkenine göre anlamlı şekilde farklılaşmaktadır ( $\mathrm{p}<.05)$. Öğretmenlerin mesleki doyum puanı diğer alanlarda çalışanların mesleki doyum puanlarından daha fazlayken Mesleki tükenmiştik tüm alt boyutları ve yaşam doyumu puanları meslek değişkenine göre anlamlı şekilde farklılaşmamaktadır $(\mathrm{p}>05)$

Tablo 3. Çalışanların Yaş Değişkeni ile Yaşam doyumu ve Mesleki doyum puanlarına Göre Varyans Analizi Sonuçları

\begin{tabular}{lllllll}
\hline \multirow{2}{*}{ Varyansın Kaynağı } & $\begin{array}{l}\text { Kareler } \\
\text { Toplamı }\end{array}$ & Sd & Krtalama & Kare & F & P \\
\hline Yaşam Doyumu & Gruplar Arası & 288,294 & 4 & 72,074 & 1,526 &, 199 \\
& Gruplar İçi & 5811,206 & 123 & 47,246 & & \\
& Toplam & 6099,500 & 127 & & & \\
\hline Mesleki Doyum & Gruplar Arası & 1715,348 & 4 & 428,837 & 2,676 &, 035 \\
& Gruplar İçi & 19710,082 & 123 & 160,245 & & \\
& Toplam & 21425,430 & 127 & & & \\
\hline
\end{tabular}


Tablo 3'te Yapılan varyans analizi sonucunda çalışanların Mesleki doyum puanları ile yaş değişkenine göre $(\mathrm{F}=1.52, \mathrm{p}<.05)$, anlamlı bir fark bulunmuştur. Gözlenen farkın hangi gruplar arasında olduğunu incelemek için LSD testi uygulanmıştır. LSD sonucuna göre 25 yaşından küçük olan çalışanların ortalamaları 56 yaşından büyük olanların ortalamasından ve 26-35 yaş aralığında olanların ortalamasından daha yüksek bulunmuştur. Yaşam doyumu puanları ile yaş değişkeni arasında anlamlı bir fark bulunamamıştır.

Tablo 4. Çalışanların Yaş Değişkenin Tükenmişlik Alt Boyutlar puanlarına göre Kruskal Wallis Testi Sonuçları

\begin{tabular}{|c|c|c|c|c|c|c|}
\hline & Yaş & $\mathbf{N}$ & $\begin{array}{l}\text { Sira } \\
\text { Ortalaması }\end{array}$ & Sd & $\chi^{2}$ & $\mathrm{p}$ \\
\hline \multirow{5}{*}{$\begin{array}{l}\text { Duygusal } \\
\text { Tükenme }\end{array}$} & 25tenküçük & 12 & 49,46 & 4 & 4.528 & .339 \\
\hline & $26-35$ & 63 & 68,58 & & & \\
\hline & $36-45$ & 31 & 57,52 & & & \\
\hline & $46-55$ & 15 & 69,90 & & & \\
\hline & 56 ve üzeri & 7 & 72,93 & & & \\
\hline \multirow{5}{*}{ Duyarsızlaşma } & 25tenküçük & 12 & 51,58 & 4 & 2.940 & .568 \\
\hline & $26-35$ & 63 & 68,58 & & & \\
\hline & $36-45$ & 31 & 63,79 & & & \\
\hline & $46-55$ & 15 & 57,17 & & & \\
\hline & 56 ve üzeri & 7 & 68,79 & & & \\
\hline \multirow{5}{*}{ Kişisel Başarı } & 25tenküçük & 12 & 72,42 & 4 & 2.071 & .723 \\
\hline & $26-35$ & 63 & 65,00 & & & \\
\hline & $36-45$ & 31 & 58,69 & & & \\
\hline & $46-55$ & 15 & 62,60 & & & \\
\hline & 56 ve üzeri & 7 & 76,21 & & & \\
\hline
\end{tabular}

Tablo $4^{\prime}$ te görülen analiz sonucuna göre çalışanların mesleki tükenmişlik tüm alt boyutları ile yaş değişkeni arasında anlamlı bir şekilde farklılaşmamaktadır ( $>$.05). 
Tablo 5. Çalışanların Medeni Durum Değişkeni ile Yaşam doyumu ve Mesleki doyum puanlarına Göre Varyans Analizi Sonuçları

\begin{tabular}{lllllll}
\hline \multirow{2}{*}{ Varyansın Kaynağı } & $\begin{array}{l}\text { Kareler } \\
\text { Toplam1 }\end{array}$ & Sd & Kare & F & P \\
\hline Yaşam Doyumu & Gruplar Arası & 57,411 & 2 & 28,706 &, 594 &, 554 \\
& Gruplar İçi & 6042,089 & 125 & 48,337 & & \\
& Toplam & 6099,500 & 127 & & & \\
\hline \multirow{2}{*}{ Mesleki Doyum } & Gruplar Arası & 297,765 & 2 & 148,882 &, 881 &, 417 \\
& Gruplar İçi & 21127,665 & 125 & 169,021 & & \\
& Toplam & 21425,430 & 127 & & & \\
\hline
\end{tabular}

Tablo 5'te Yapılan varyans analizi sonucunda çalışanların Mesleki doyum ve Yaşam doyumu puanları medeni durum değişkenine göre anlamlı bir fark göstermemektedir ( $\mathrm{p}>.05)$.

Tablo $6^{\prime}$ da görülen analiz sonucuna göre çalışanların mesleki tükenmişlik tüm alt boyutları ile medeni durum değişkeni arasında anlamlı bir şekilde farklılaşmamaktadır ( $\mathrm{p}>$.05).

Tablo 6. Çalışanların Medeni Durum Değişkenin Tükenmişlik Alt Boyutları puanlarina göre Kruskal Wallis Testi Sonuçları

\begin{tabular}{|c|c|c|c|c|c|c|}
\hline & Medeni Durum & $\mathbf{N}$ & Sira Ortalaması & Sd & $\chi^{2}$ & p \\
\hline \multirow{3}{*}{$\begin{array}{l}\text { Duygusal } \\
\text { kenme }\end{array}$} & Evli & 85 & 66,37 & 2 & 1.040 & .595 \\
\hline & Bekar & 39 & 59,67 & & & \\
\hline & Boşanmış & 4 & 71,88 & & & \\
\hline \multirow{3}{*}{ Duyarsızlaşma } & Evli & 85 & 66,05 & 2 & .447 & .800 \\
\hline & Bekar & 39 & 61,53 & & & \\
\hline & Boşanmış & 4 & 60,63 & & & \\
\hline \multirow{3}{*}{ Kişisel Başarı } & Evli & 85 & 61,83 & 2 & 2.469 & .291 \\
\hline & Bekar & 39 & 67,85 & & & \\
\hline & Boşanmış & 4 & 88,63 & & & \\
\hline
\end{tabular}


Tablo 7. Çalışanların Mesleki Kıdem Değişkeni ile Yaşam doyumu, Mesleki doyum ve Tükenmişlik Alt Boyutları puanlarına göre Varyans Analizi Sonuçları

\begin{tabular}{|c|c|c|c|c|c|c|}
\hline \multirow{2}{*}{\multicolumn{2}{|c|}{ Varyansın Kaynağ1 }} & \multirow{3}{*}{$\begin{array}{l}\text { Kareler } \\
\text { Toplam1 } \\
242,913\end{array}$} & \multirow{3}{*}{$\begin{array}{l}\mathrm{Sd} \\
5\end{array}$} & \multicolumn{3}{|c|}{ Ortalama } \\
\hline & & & & Kare & $\mathrm{F}$ & $\mathrm{P}$ \\
\hline \multirow{3}{*}{$\begin{array}{l}\text { Duyusal } \\
\text { Tükenme }\end{array}$} & Gruplar Arası & & & 48,583 & 1,394 & 231 \\
\hline & Gruplar İçi & 4252,306 & 122 & 34,855 & & \\
\hline & Toplam & 4495,219 & 127 & & & \\
\hline \multirow[t]{3}{*}{ Duyarsızlaşma } & Gruplar Arası & 43,263 & 5 & 8,653 & ,787 & $\overline{5,561}$ \\
\hline & Gruplar İçi & 1340,730 & 122 & 10,990 & & \\
\hline & Toplam & 1383,992 & 127 & & & \\
\hline \multirow[t]{3}{*}{ Kişisel Başarı } & Gruplar Arası & 27,063 & 5 & 5,413 & 241 & 944 \\
\hline & Gruplar İçi & 2745,055 & 122 & 22,500 & & \\
\hline & Toplam & 2772,117 & 127 & & & \\
\hline \multirow[t]{3}{*}{ Mesleki Doyum } & Gruplar Arası & 625,244 & 5 & 125,049 & ,733 & 600 \\
\hline & Gruplar İçi & 20800,185 & 122 & 170,493 & & \\
\hline & Toplam & 21425,430 & 127 & & & \\
\hline \multirow[t]{3}{*}{ Yaşam Doyumu } & Gruplar Arası & 88,042 & 5 & 17,608 &, 357 & 877 \\
\hline & Gruplar İçi & 6011,458 & 122 & 49,274 & & \\
\hline & Toplam & 6099,500 & 127 & & & \\
\hline
\end{tabular}

Tablo 7' de yapılan varyans analizi sonucuna göre çalışanların yaşam doyumu, mesleki doyum ve tükenmişlik alt boyutları puanları mesleki k1dem değişkenine göre anlamlı bir şekilde farklılaşmamaktadır ( $\mathrm{p}>.05)$.

Tablo 8. Çalışanların Algıladıkları Sosyo-Ekonomik Durum Değişkenin Tükenmişlik Alt Boyutları puanlarna göre Kruskal Wallis Testi Sonuçları

\begin{tabular}{|c|c|c|c|c|c|c|}
\hline & $\begin{array}{l}\begin{array}{l}\text { Sosyo- } \\
\text { ekonomi }\end{array}\end{array}$ & $\mathbf{N}$ & $\begin{array}{l}\text { Sira } \\
\text { Ortalamas1 }\end{array}$ & Sd & $\chi^{2}$ & $\mathrm{p}$ \\
\hline \multirow{3}{*}{ Duyusal Tükenme } & Üst & 5 & 37,10 & 2 & 4.31 & .116 \\
\hline & Orta & 109 & 64,17 & & & \\
\hline & Alt & 14 & 76,89 & & & \\
\hline \multirow{3}{*}{ Duyarsızlaşma } & Üst & 5 & 70,60 & 2 & .151 & .927 \\
\hline & Orta & 109 & 64,14 & & & \\
\hline & Alt & 14 & 65,14 & & & \\
\hline \multirow{3}{*}{ Kişisel Başarı } & Üst & 5 & 57,00 & 2 & .251 & .882 \\
\hline & Orta & 109 & 65,03 & & & \\
\hline & Alt & 14 & 63,04 & & & \\
\hline
\end{tabular}

Tablo 8' de görülen analiz sonucuna göre çalışanların mesleki tükenmişlik tüm alt boyutları ile algıladıkları sosyo-ekonomik durum değişkeni arasinda anlamlı bir farkl1lik yoktur ( $\mathrm{p}>.05)$. 
Tablo 9. Çalışanların Algıladıkları Sosyo-Ekonomik Durum Değişkeni ile Yaşam doyumu ve Mesleki doyum puanlarna göre Varyans Analizi Sonuçları

\begin{tabular}{|c|c|c|c|c|c|c|c|c|c|}
\hline & & $\mathbf{N}$ & $\overline{\boldsymbol{X}}$ & $\begin{array}{l}\text { Varyansın } \\
\text { Kaynagı }\end{array}$ & $\begin{array}{l}\text { Kareler } \\
\text { Toplamı }\end{array}$ & Sd & $\begin{array}{l}\text { Orta- } \\
\text { lama } \\
\text { Kare } \\
\end{array}$ & $\mathbf{F}$ & $\mathbf{P}$ \\
\hline & Üst & 5 & 74,00 & $\begin{array}{l}\text { Gruplar } \\
\text { Arası }\end{array}$ & 868,064 & 2 & 434,032 & 2,639 & ,075 \\
\hline \multirow[t]{3}{*}{$\begin{array}{l}\text { Mesleki } \\
\text { Doyum }\end{array}$} & Orta & 109 & 73,15 & $\begin{array}{l}\text { Gruplar } \\
\text { İçi }^{\text {Ge }}\end{array}$ & 20557,366 & 125 & 164,459 & & \\
\hline & Alt & 14 & 64,86 & Toplam & 21425,430 & 127 & & & \\
\hline & Üst & 5 & 25,60 & $\begin{array}{l}\text { Gruplar } \\
\text { Arası }\end{array}$ & 497,136 & 2 & 248,568 & 5,546 & ,005 \\
\hline \multirow[t]{2}{*}{$\begin{array}{l}\text { Yaşam } \\
\text { Doyumu }\end{array}$} & Orta & 109 & 23,26 & $\begin{array}{l}\text { Gruplar } \\
\text { İçi }\end{array}$ & 5602,364 & 125 & 44,819 & & \\
\hline & Alt & 14 & 17,21 & Toplam & 6099,500 & 127 & & & \\
\hline
\end{tabular}

Tablo 9'da görülen analiz sonucuna göre çalışanların algıladıkları sosyo-ekonomik düzey değişkenine göre yaşam doyumları puanları arasinda anlamlı bir farklılık vardır ( $\mathrm{p}<.05)$. Bu farklılığın hangi gruplar arasında olduğunu saptamak amacıyla LSD testi yapılmışır bu testin sonucuna göre sosyo-ekonomik düzeyini üst düzeyde algılayanların puan ortalaması orta düzeyde algılayanlardan ve alt düzeyde algılayanların puan ortalamasından fazladır. Çalışanların mesleki doyum puanları algıladıkları sosyo- ekonomik düzey değişkenine göre farklılaşmamaktadır ( $\mathrm{p}>$.05).

Tablo 10'da görülen varyans analizi sonucuna göre çalışanların kişiliklerinin mesleklerine uygunluk düzeyleri ile mesleki tükenmişlik alt boyutu olan duygusal tükenme arasında anlamlı bir farklılık vardır $(\mathrm{p}<.05)$. Bu farklılığın hangi gruplar arasında olduğunu belirlemek için LSD testi uygulanmıştır. Bu testin sonucuna göre; kişiliklerinin mesleklerine çok uygun olduğunu belirten kişilerin puan ortalaması uygun olarak belirtenlerin ortalamasından fazladır, ayrıca kişilik özelliklerinin mesleğine kısmen uygun olduğunu belirtenlerin ortalaması da çok uygun diye belirtenlerin ortalamasından daha fazladır. Çalışanların kişiliklerinin mesleklerine uygunluk düzeyleri ile mesleki tükenmişlik alt boyutu olan kişisel başarı arasında anlamlı bir farklılık vardır ( $\mathrm{p}<.05)$. Bu farklılığın hangi gruplar arasında olduğunu belirlemek için LSD testi uygulanmıştır. Bu 
testin sonucuna göre kişiliklerinin mesleklerine çok uygun olduğunu belirten kişilerin puan ortalaması uygun ve kısmen uygun diyenlerin ortalamasından daha fazladır. Tabloda görüldüğü üzere çalışanların kişiliklerinin mesleklerine uygunluk düzeyleri ile mesleki doyum puanları arasında anlamlı bir farklılık vardır ( $p<.05)$. LSD testi sonucuna göre kişiliklerinin mesleklerine uygun olduğunu belirtenlerin ortalaması kısmen uygun diye belirtenlerin ve çok uygun diye belirtenlerin ortalamasından daha fazladır.

Tablo 10. Çalışanların Kişilik Özelliklerinin Mesleğe Uygunluğu ile Yaşam doyumu, Mesleki doyum ve Tükenmişlik Alt Boyutlarn puanlarna göre Varyans Analizi Sonuçları

\begin{tabular}{|c|c|c|c|c|c|c|c|c|c|}
\hline & & \multirow{2}{*}{$\mathbf{N}$} & \multirow{2}{*}{$\overline{\boldsymbol{X}}$} & \multirow{2}{*}{$\begin{array}{l}\text { Varyansın } \\
\text { Kaynagı }\end{array}$} & \multicolumn{2}{|l|}{ Kareler } & \multicolumn{2}{|l|}{ Ortalama } & \multirow[b]{2}{*}{$\mathbf{P}$} \\
\hline & & & & & Toplamı & Sd & Kare & F & \\
\hline \multirow{3}{*}{ DT } & $\begin{array}{l}\text { Çok uy- } \\
\text { gun }\end{array}$ & 37 & 19,30 & $\begin{array}{l}\text { Gruplar } \\
\text { Arasi }\end{array}$ & 322,673 & 2 & 161,33 & 4,833 & , 010 \\
\hline & $\begin{array}{l}\text { Kismen } \\
\text { uygun }\end{array}$ & 32 & 23,53 & Gruplar İçi & 4172,546 & 125 & 33,380 & & \\
\hline & Uygun & 59 & 21,95 & Toplam & 4495,219 & 127 & & & \\
\hline \multirow{3}{*}{ D } & $\begin{array}{l}\text { Çok uy- } \\
\text { gun }\end{array}$ & 37 & 8,84 & $\begin{array}{l}\text { Gruplar } \\
\text { Arası }\end{array}$ & 32,852 & 2 & 16,426 & 1,520 & 223 \\
\hline & $\begin{array}{l}\text { Kismen } \\
\text { uygun }\end{array}$ & 32 & 10,22 & Gruplar İçi & 1351,140 & 125 & 10,809 & & \\
\hline & Uygun & 59 & 9,54 & Toplam & 1383,992 & 127 & & & \\
\hline \multirow{3}{*}{ KB } & $\begin{array}{l}\text { Çok uy- } \\
\text { gun }\end{array}$ & 37 & 31,00 & $\begin{array}{l}\text { Gruplar } \\
\text { Aras1 }\end{array}$ & 171,710 & 2 & 85,855 & 4,127 & ,018 \\
\hline & $\begin{array}{l}\text { Kismen } \\
\text { uygun }\end{array}$ & 32 & 28,25 & Gruplar İçi & 2600,407 & 125 & 20,803 & & \\
\hline & Uygun & 59 & 28,58 & Toplam & 2772,117 & 127 & & & \\
\hline \multirow{3}{*}{ MD } & $\begin{array}{l}\text { Çok uy- } \\
\text { gun }\end{array}$ & 37 & 79,30 & $\begin{array}{l}\text { Gruplar } \\
\text { Arası }\end{array}$ & 2792,824 & 2 & 1396,412 & 9,368 & , 000 \\
\hline & $\begin{array}{l}\text { Kismen } \\
\text { uygun }\end{array}$ & 32 & 67,28 & Gruplar İçi & 18632,605 & 125 & 149,061 & & \\
\hline & Uygun & 59 & 70,58 & Toplam & 21425,430 & 127 & & & \\
\hline \multirow{3}{*}{ YD } & $\begin{array}{l}\text { Çok uy- } \\
\text { gun }\end{array}$ & 37 & 24,27 & $\begin{array}{l}\text { Gruplar } \\
\text { Arası }\end{array}$ & 234,179 & 2 & 117,089 & 2,495 & , 087 \\
\hline & $\begin{array}{l}\text { Kismen } \\
\text { uygun }\end{array}$ & 32 & 20,59 & Gruplar İçi & 5865,321 & 125 & 46,923 & & \\
\hline & Uygun & 59 & 22,83 & Toplam & 6099,500 & 127 & & & \\
\hline
\end{tabular}


Tablo 11. Çalışanların Mesleklerini yaparken üstlerinizden takdir görme durumlarının Tükenmişlik Alt Boyutları puanlarına Göre Varyans Analizi Sonuçları

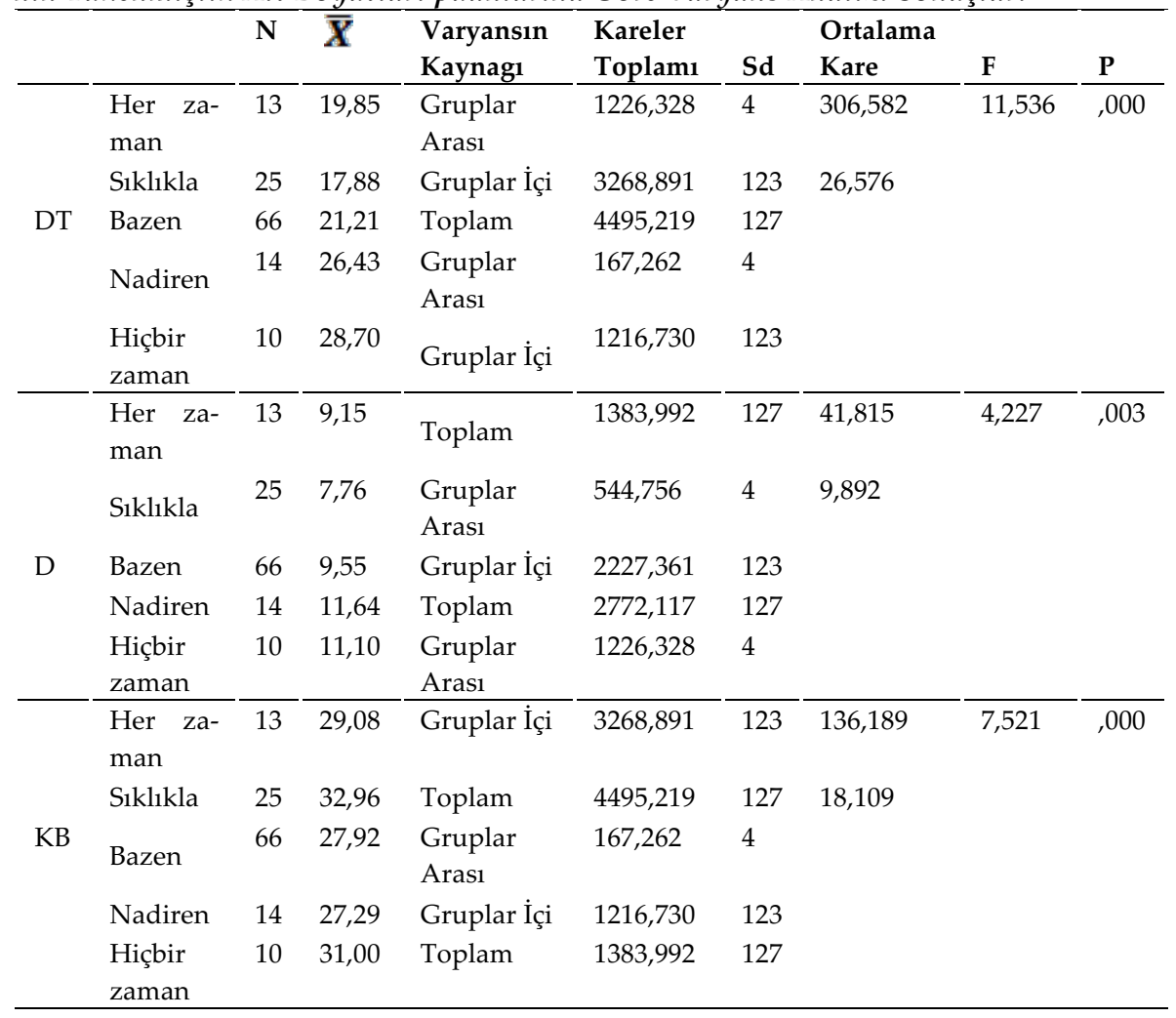

Tablo 11'de görülen varyans analizi sonucuna göre çalışanların mesleklerini yaparken üstlerinizden takdir görme düzeyleri ile mesleki tükenmişlik alt boyutu olan duygusal tükenme arasında anlamlı bir farklılık vardır ( $\mathrm{p}<.05)$. Bu farklılığın hangi gruplar arasında olduğunu belirlemek için LSD testi uygulanmıştır. Bu testin sonucuna göre; çalışanların mesleklerini yaparken hiçbir zaman takdir görmediğini söyleyenlerin ortalaması bazen takdir görenlerden, her zaman takdir görenlerden ve sıklıkla takdir görenlerin ortalamasından fazladır. Çalışanların mesleklerini yaparken üstlerinizden takdir görme düzeyleri ile mesleki tükenmişlik alt boyutu olan duyarsızlaşma arasında anlamlı bir farklılık vardır $(\mathrm{p}<.05)$. 
LSD testi sonucuna göre; çalışanların mesleklerini yaparken nadiren takdir gördügünü söyleyenlerin ortalaması bazen takdir görenlerin ortalamasından fazladır. Ayrıca tablaya göre çalışanların mesleklerini yaparken üstlerinizden takdir görme düzeyleri ile mesleki tükenmişlik alt boyutu olan kişisel başarı arasında anlamlı bir farklılık vardır ( $\mathrm{p}<.05)$. LSD testi sonucuna göre çalışanların mesleklerini yaparken üstlerinden hiçbir zaman takdir görmediğini söyleyenlerin ortalaması bazen ve nadiren takdir görenlerin ortalamasından fazladır. Üstlerinden sıklıkla takdir görenlerin ortalaması da her zaman takdir görenlerden ve nadiren takdir görenlerin ortalamasından fazladır.

Tablo 12. Çalı̧̧anların Mesleklerini yaparken üstlerinizden takdir görme düzeyi Değişkenin Mesleki doyum ve Yaşam doyumu puanlarına göre Kruskal Wallis Testi Sonuçları

\begin{tabular}{|c|c|c|c|c|c|c|}
\hline & & $\mathbf{N}$ & $\begin{array}{l}\text { Sira } \\
\text { Ortalaması }\end{array}$ & $S d$ & $\chi^{2}$ & p \\
\hline \multirow{5}{*}{$\begin{array}{l}\text { Mesleki } \\
\text { Doyum }\end{array}$} & Her zaman & 13 & 63,96 & \multirow[t]{5}{*}{4} & \multirow[t]{5}{*}{41,214} & \multirow[t]{5}{*}{.00} \\
\hline & S1klıkla & 25 & 98,26 & & & \\
\hline & Bazen & 66 & 64,27 & & & \\
\hline & Nadiren & 14 & 30,32 & & & \\
\hline & $\begin{array}{l}\text { Hiçbir za- } \\
\text { man }\end{array}$ & 10 & 30,15 & & & \\
\hline \multirow{5}{*}{$\begin{array}{l}\text { Yaşam } \\
\text { Doyumu }\end{array}$} & Her zaman & 13 & 67,00 & \multirow[t]{5}{*}{4} & \multirow[t]{5}{*}{11,502} & \multirow[t]{5}{*}{.021} \\
\hline & Siklıkla & 25 & 71,92 & & & \\
\hline & Bazen & 66 & 69,53 & & & \\
\hline & Nadiren & 14 & 40,43 & & & \\
\hline & $\begin{array}{l}\text { Hiçbir } \\
\text { man }\end{array}$ & 10 & 43,20 & & & \\
\hline
\end{tabular}

Tablo 12' de görülen analiz sonucuna göre çalışanların mesleklerini yaparken üstlerinizden takdir görme düzeyleri ile mesleki doyum puanları arasında anlamlı bir farklılık vardır $(\mathrm{p}<.05)$. Gruplar arasındaki farkın hangi gruplar arasında olduğunu saptamak amaciyla ikili gruplar arasında Mann-Whitney U testi uygulanmıştır. Mann Whitney U-testi sonuçlarına göre üstlerinden sıklıkla takdir görenlerin mesleki doyum puanları üstlerinde her zaman takdir görenlerin ortalamasından fazladır. Her zaman takdir görenlerin ortalaması nadiren görenlerden ve hiçbir zaman 
göremeyenlerin ortalamasından fazladır. Üstlerinden sıklıkla takdir ald1ğını belirtenlerin mesleki doyum puanları bazen takdir alanlardan, nadiren takdir alanlardan ve hiçbir zaman takdir almayanların ortalamasından daha fazladır. Bazen takdir aldığını ifade eden çalışanların mesleki doyum puanları nadiren takdir görenlerin ortalamasından ve hiçbir zaman takdir görmeyenlerin ortalamasından daha fazladır. Yine tablo 12' ye baktı̆̆ımızda çalışanların mesleklerini yaparken üstlerinizden takdir görme düzeyleri ile yaşam doyumu puanları arasında anlamlı bir farklılık vardır ( $\mathrm{p}<.05)$. Gruplar arasındaki farkın hangi gruplar arasında oldugunu saptamak amaciyla ikili gruplar arasında Mann-Whitney U testi uygulanmıştır. Mann Whitney U-testi sonuçlarına göre üstlerinden her zaman takdir aldığını belirtenlerin yaşam doyumu puan ortalamaları, nadiren takdir alanların puan ortalamasından fazladır. Üstlerinden sıklıkla takdir görenlerin yaşam doyumu puan ortalamaları hiçbir zaman takdir görmeyenlerden ve nadiren takdir görenlerin ortalamasından fazladır.

\section{Tartışma ve Sonuç}

Çalışanların Mesleki doyum puanları ve Yaşam doyumu puanları cinsiyet değişkenine göre anlamlı şekilde farklılaşmaktadır. İkisinde de kadın çalışanların ortalaması erkeklerin ortalamasından fazladır. Avşaroğlu, Deniz ve Kahraman (2005) tarafından yapılan çalışmada erkeklerin yaşam doyumu puan ortalaması kadınların ortalamasından daha fazladır. Uğur (2015) tarafından yapılan çalışmada cinsiyet değişkeni mesleki doyum düzeyini anlamlı bir şekilde etkilemediği sonucuna ulaşılmıştır. Mesleki tükenmiştik tüm alt boyutları cinsiyet değişkenine göre anlamlı şekilde farklılaşmamaktadır. Alan yazın incelendiğinde Dolunay (2002) ve Çokluk (1999) tarafından yapılan çalışma sonuçları bizim bulgularımızı desteklemektedir. Bununla birlikte Çokluk (2001) Barut ve Kalkan (2002), Vızlı (2005) ve Çoban Kaynak (2018) ise yaptıkları çalışmalarda mesleki tükenmişlik düzeylerinin cinsiyet değişkenine göre anlamlı şekilde farklılaştığ 1 sonucuna ulaşmışlardır.

Çalışanların mesleki doyum puanları meslek değişkenine göre anlamlı şekilde farklılaşmaktadır. Öğretmenlerin mesleki doyum puanı diğer 
alanlarda çalışanların mesleki doyum puanlarından daha fazlayken Mesleki tükenmiştik tüm alt boyutları ve yaşam doyumu puanları meslek değişkenine göre anlamlı şekilde farklılaşmamaktadır.

Çalışanların mesleki doyum puanları ile yaş değişkenine göre anlamlı bir fark bulunmuştur. 25 yaşından küçük olan çalışanların ortalamaları 56 yaşından büyük olanların ortalamasından ve 26-35 yaş aralığında olanların ortalamasından daha yüksek bulunmuştur. Yaşam doyumu puanları ve mesleki tükenmişlik tüm alt boyutları ile yaş değişkeni arasında anlamlı bir fark bulunamamıştır. Recepoglu ve Ülker Tümlü (2015) tarafından yapılan çalışmada yaşam doyumu cinsiyet e göre farklılaşmamaktadır. Alan yazın incelendiğinde mesleki tükenmişlik ile yaş değişkeni arasındaki ilişkiyi inceleyen pek çok araştırma bulunmaktadır. Taşğıı (2004) ve Korkutan (2018) tarafından yapılan çalışmaların bulguları bizim bulgularımızı destekler niteliktedir. Öte yandan Sucuoğlu ve Kuloğlu (1996), Baysal (1995), Dolunay (2002) ve Gürbüz (2008) tarafından yapılan çalışmalarda yaş değişkeni mesleki tükenmişlik düzeylerini etkilemektedir.

Çalışanların medeni durum değişkeni ile yaşam doyumu, mesleki doyum ve tükenmişlik alt boyutları arasında anlamlı bir farklılık bulunamamıştır. Kaynak Çoban (2018) ve Korkut (2017) tarafından yapılan çalışmalarda mesleki tükenmişlik puanları mesleki kıdem değişkenine göre anlamlı bir şekilde farklılaşmamaktadır. Işıkhan (2000)'ın kıdem yılı ile mesleki doyum arasındaki ilişkiyi incelediği çalışmasına göre mesleki doyumu ile hizmet süreleri arasında anlamlı bir ilişki tespit edilememiştir.

Çalışanların mesleki tükenmişlik tüm alt boyutları ve mesleki doyum düzeyleri ile algıladıkları sosyo-ekonomik durum değişkeni arasında anlamlı bir farklılık yoktur. Çalışanların algıladıkları sosyo-ekonomik düzey değişkenine göre yaşam doyumları puanları arasında anlamlı bir farklılık vardır Sosyo-ekonomik düzeyini üst düzeyde algılayanların puan ortalaması orta düzeyde algılayanlardan ve alt düzeyde algılayanların puan ortalamasından fazladır. Vızlı (2005) tarafından yapılan çalışmada mesleki tükenmişlik düzeyi algılanan sosyo-ekonomik düzeye göre anlamlı bir şekilde farklılaşmaktadır.

Çalışanların kişiliklerinin mesleklerine uygunluk düzeyleri ile mesleki tükenmişlik alt boyutu olan duygusal tükenme arasında anlamlı bir farklılık vardır. Kişiliklerinin mesleklerine çok uygun olduğunu belirten kişilerin puan ortalaması uygun olarak belirtenlerin ortalamasından fazladır, 
ayrıca kişilik özelliklerinin mesleğine kısmen uygun olduğunu belirtenlerin ortalaması da çok uygun diye belirtenlerin ortalamasından daha fazladır. Çalışanların kişiliklerinin mesleklerine uygunluk düzeyleri ile mesleki tükenmişlik alt boyutu olan kişisel başarı arasında anlamlı bir farklılık vardır. Kişiliklerinin mesleklerine çok uygun olduğunu belirten kişilerin puan ortalaması uygun ve kısmen uygun diyenlerin ortalamasından daha fazladır. Çalışanların kişiliklerinin mesleklerine uygunluk düzeyleri ile mesleki doyum puanları arasında anlamlı bir farklılık vardır kişiliklerinin mesleklerine uygun olduğunu belirtenlerin ortalaması kısmen uygun diye belirtenlerin ve çok uygun diye belirtenlerin ortalamasından daha fazladir.

Çalışanların mesleklerini yaparken üstlerinizden takdir görme düzeyleri ile mesleki tükenmişlik alt boyutu olan duygusal tükenme, duyarsızlaşma ve kişisel başarı arasında anlamlı bir farklılık vardır. Tunaboylu (2015) tarafından yapılan çalışma bu araştırma sonuçlarını desteklemektedir. Çalışanların mesleklerini yaparken üstlerinizden takdir görme düzeyleri ile mesleki doyum puanları arasında anlamlı bir farklılık vardır. Çalışanların mesleklerini yaparken üstlerinizden takdir görme düzeyleri ile yaşam doyumu puanları arasında anlamlı bir farklılık vardır. 


\title{
EXTENDED ABSTRACT
}

\section{Investigation of Occupational Burnout, Occupational Satisfaction and Life Satisfaction of Employees}

\author{
Bünyamin Çetinkaya - Fikret Gülaçti - Zeynep Çiftci \\ Giresun University, Binali Yaldırım University
}

Kuzgun (1982), while defining the profession, stated that the profession can be said to be a means of using and developing talents, self-realization, and self-expression beyond the way of earning money and making a living. Individuals satisfy their needs such as status, recognition and achievement through their jobs and professions and establish relations with the society. Profession and work contribute to the development of self-esteem of individuals. People who work and engage in different activities to produce something feel valued and their self-esteem is strengthened.

Burnout is one of the important concepts faced by industry and modern society. According to Maslach and Zimbargo (1982), burnout is defined as emotional exhaustion, depersonalization, and low personal accomplishment seen in those who are intensely involved with people in their jobs. Emotional exhaustion according to Maslach, Schaufeli, Leiter, (2001) and Wright and Douglas (1997); indicates the individual stress dimension of burnout and indicates a decrease in the individual's emotional and physical resources. Depersonalization represents the interpersonal dimension of burnout and indicates negative, rigid attitudes towards customers and non-responsiveness to work.

Satisfaction or dissatisfaction that an individual receives from his / her profession may affect everyone in his / her environment. According to Çakan (2013), professional satisfaction is the accumulation of people's beliefs and feelings about their existing relationships. According to Tekin, Bozkır, Sazak, and Özer (2014), this accumulation of emotions manifests itself positively or negatively in practice and in work performances. As a result of low saturation level, many negative conditions such as lack of concentration, probability of error, and irritability manifest themselves. According to Deiner and Deiner (1995), life satisfaction is in a sense the degree of achievement of the goals set by the individual. Deiner (1984) 
stated that increasing the level of reaching individual goals increases life satisfaction. Cognitive judgments about positive emotions and satisfaction (Diener and Suh, 1997; Diener and Larsen, 1993; Gülaçtı, 2010; Yiğit, 2013; Gülaçt1, 2014) may be related to various living spaces and the sum of these reflects the overall life satisfaction (Gülaçtı, 2009). The aim of this study is to determine how the levels of professional satisfaction, burnout and life satisfaction of teachers, academicians and other employees are affected by some variables.

The study group consisted of schools affiliated to Ministry of National Education, academicians working in Vocational High School and 128 other people working in state or private institutions in Refahiye district of Erzincan. In the research, cluster sampling technique (disproportionate cluster sampling) was used. According to this technique, research can be done on the clusters to be selected from the universe. Cluster sampling technique is the sampling technique in which all clusters in the universe have equal chance to be selected individually (together with all elements) (Karasar, 1995: 114-115). As a data collection tool, a Personal Information Form which was prepared by the researchers for the purpose of the research, Maslach Burnout Inventory, Occupational Satisfaction Scale and Life Satisfaction Scale were used.

Parametric and nonparametric statistical methods were used in the study. The scores obtained from professional satisfaction, professional burnout, and life satisfaction scales were continuous variables and were considered as dependent variables of the study. Research data were subjected to normality tests and analyzes were made according to the results. Data were analyzed with Mann Whitney U Test, Kruskal Wallis H Test and Anova. SPSS 22.0 Statistical analysis program was used in the data analysis part of the study.

Occupational Satisfaction and Life Satisfaction scores of employees differ significantly according to gender. In both, the average of female employees is higher than that of men. In the study conducted by Avşaroğlu, Deniz and Kahraman (2005), the average life satisfaction score of men is higher than the average of women. All sub-dimensions of occupational exhaustion did not differ significantly according to the gender variable. When the literature is examined, the results of the study conducted by Dolunay (2002) and Çokluk (1999) support our findings. On the other 
hand, Çokluk (2001) Barut and Kalkan (2002), Vızlı (2005) and Çoban Kaynak (2018) concluded that occupational burnout levels differ significantly according to gender.

The professional satisfaction scores of the employees differ significantly according to the profession variable. While the teachers' professional satisfaction scores were higher than those of employees working in other fields; all sub-dimensions and life satisfaction scores did not differ significantly according to occupational variables.

A significant difference was found according to the employee satisfaction scores and age variable. The average of the employees under the age of 25 was higher than the average of those over the age of 56 and the average of those between the ages of 26-35. There was no significant difference between life satisfaction scores and all sub-dimensions of professional burnout and age variable. In the study conducted by Recepoglu and Ülker Tümlü (2015), life satisfaction did not differ according to gender. No significant difference was found between the marital status variable and life satisfaction, occupational satisfaction and burnout sub-dimensions of the employees. In the studies conducted by Kaynak Çoban (2018) and Korkut (2017), professional burnout scores do not differ significantly according to the professional seniority variable. There is no significant difference between all the sub-dimensions of professional burnout and occupational satisfaction levels of the employees and the variables of perceived socio-economic status. There is a significant difference between life satisfaction scores according to the socio-economic level variable perceived by the employees. The average score of those who perceive the socio-economic level at higher level is higher than the ones who perceive the middle level and those who perceive the lower level. In the study conducted by Vizlı (2005), occupational burnout levels differ significantly according to perceived socio-economic level.

There is a significant difference between the level of suitability of employees' personalities to their occupations and emotional exhaustion which is the sub-dimension of professional burnout. The average score of the individuals who stated that their personalities were very suitable for their profession was higher than the average of those who indicated that they were suitable for their profession, and the average of those who 
stated that their personality traits were partially suitable for their profession was higher than the average of those who stated that they were very suitable. There is a significant difference between the level of suitability of employees' personalities to their occupations and personal achievement which is the sub-dimension of professional burnout. The average score of those who stated that their personalities were very suitable for their profession was higher than the average of those who said that they were appropriate and partly appropriate. There is a significant difference between the level of suitability of the personalities of the employees for their occupations and their professional satisfaction scores. The average of those who stated that their personalities were appropriate for their profession was higher than the average of those who stated that they were partially eligible and those who stated that they were very suitable.

There is a significant difference between the level of appreciation of the employees while they are doing their jobs and emotional exhaustion, depersonalization and personal success which is the sub-dimension of professional burnout. Tunaboylu (2015) supports the results of this research. There is a significant difference between the levels of appreciation of the employees and their professional satisfaction scores. There is a significant difference between the levels of appreciation of the employees and their life satisfaction scores.

\section{Kaynakça / References}

Avşaroğlu, S., Deniz, M. E., ve Kahraman, A. (2005). Teknik öğretmenlerde yaşam doyumu iş doyumu ve mesleki tükenmişlik düzeylerinin incelenmesi. Selçuk Üniversitesi Sosyal Bilimler Enstitüsü Dergisi, 14, 115129.

Barut, Y. ve Kalkan, M. (2002). Ondokuz Mayıs Üniversitesi öğretim elemanlarının tükenmişlik düzeylerinin incelenmesi. Samsun: Ondokuz Mayıs Üniversitesi Eğitim Fakültesi Dergisi, 14, 66-77

Baysal, A. (1995). Lise ve dengi okul öğretmenlerinde meslekte tükenmişliğe etki eden faktörler. Yayınlanmamış Doktora Tezi. İzmir: Dokuz Eylül Üniversitesi Sosyal Bilimler Enstitüsü. 
Çakan, B. K. (2013). Konut sektöründe beyaz yaka çalışanların iş doyumu ve duygusal zekâlarının yaşam doyumu üzerine etkisi. Yayımlanmamış Yüksek Lisans Tezi, Maltepe Üniversitesi, Sosyal Bilimler Enstitüsü, İstanbul.

Çam, O. (1992). Tükenmişlik envanterinin geçerlik ve güvenirliğinin araştırılması. VII. Ulusal Psikoloji Kongresi Bilimsel Çalısmaları El Kitabı, 1992, Ankara, 155-166.

Çoban-Kaynak, R. (2018). Kurumsal bakım hizmeti veren kuruluşlarda çalı̧an personelin mesleki doyum ve tükenmişlik düzeyi: Gümüşhane İli örneği. Yayımlanmamış Yüksek Lisans Tezi, Ankara Yıldırım Beyazıt Üniversitesi Sağlık Bilimleri Enstitüsü

Çokluk, Ö. (1999). Zihinsel ve işitme engelliler okulunda görev yapan yönetici ve öğretmenlerde tükenmişliğin kestirilmesi. Yayınlanmamış Yüksek Lisans Tezi, Ankara Üniversitesi Sosyal Bilimler Enstitüsü, Ankara.

Çokluk, Ö. (2001). Engelliler okullarında görev yapan yöneticilerde ve öğretmenlerde tükenmişlik. Özel Ĕ̆itim Dergisi, 3(1), 35-47.

Diener, E. (1984). Subjective well-being. Psychological Bulletin, 95(3), 542-575.

Diener, E., Diener, M. (1995). Cross-cultural correlates of life satisfaction and self-esteem. Journal of Personality and Social Psychology 68, 653-663.

Diener, E., ve Larsen, R. J. (1993). The experience of emotional well-being. In (Ed. I. M. Lewis, J. M. Haviland), Handbook of Emotions, New York: Guildford,

Diener, E., ve Suh, E. (1997), Measuring quality of life: economic, social, and subjective indicators, Social Indicators Research, 40(1-2), 189-216.

Dolunay, A.B (2002). Genel liseler ve teknik-ticaret-meslek liselerinde görevli öğretmenlerde tükenmişlik durumu. Ankara: Ankara Üniversitesi Tip Fakültesi Mecmuası. 55 (1), 51-62.

Ergin, C. (1992). Doktor ve hemşirelerde tükenmişlik ve maslach tükenmişlik ölçeği'nin uyarlanması. VII. Ulusal Psikoloji Kongresi Bilimsel Çalışmalar. Ankara:Türk Psikologlar Derneği Yayınları,143-154.

Gülaçtı, F. (2009). Sosyal beceri eğitimine yönelik programın üniversite öğrencilerinin, sosyal beceri, öznel ve psikolojik iyi olma düzeylerine etkisi. Yayınlanmamış Doktora Tezi, Atatürk Üniversitesi, Sosyal Bilimler Enstitüsü, Erzurum.

Gülaçt1, F. (2010). The effect of perceived social support on subjective wellbeing. Procedia Social and Behavioral Sciences, 2, 3844-3849. 
Gülaçtı, F. (2014). Investigating university students' predictors of psychological well-being. International Journal of Academic Research, 6(1), 318-324.

Gürbüz , Z. (2008). Kars ilinde görevli okul öncesi öğretmenlerinin iş tatmin düzeyleri ve mesleki tükenmişlik düzeylerinin incelenmesi. Yayımlanmış Yüksek Lisans Tezi, Marmara Üniversitesi, Sosyal Bilimler Enstitüsü, Ankara. Işıkhan V. (2000). Sosyal hizmet uzmanlarının iş doyumu. Toplum ve Sosyal Hizmet, 1, 38-52

Karasar, N. (1995). Bilimsel araştırma yöntemi, Ankara: 3A Araştırma Eğitim Danışmanlık Ltd.

Korkut A. (2017). Engelli bakım ve rehabilitasyon merkezlerinde çalışan bakım elemanlarının bağlanma yönelimleri, stresle başa çıkma tarzları, sosyal destek algıları, psikolojik belirtiler ve bazı demografik özelliklerin tükenmişlik ile ilişkisi, Yayımlanmamış Yüksek lisans tezi, Fatih Sultan Mehmet Vakıf Üniversitesi, Sosyal Bilimler Enstitüsü

Korkutan, T. (2018). Meslek liselerinde çalışan öğretmenlerin mesleki doyumu ile tükenmişlik düzeyleri arasındaki ilişkinin incelenmesi. Yayımlanmamış Yüksek Lisans Tezi. İstanbul Aydın Üniversitesi Sosyal Bilimler Enstitüsü

Köker, S. (1991). Normal ve sorunlu ergenlerin yaşam doyumu düzeylerinin karşılaştırılması, Yayınlanmamış Yüksek Lisans Tezi, Ankara Üniversitesi Sosyal Bilimler Enstitüsü.

Kuzgun, Y. (1982). Meslekî rehberliğin bireylerin yetenek ve ilgilerine uygun meslekleri tanımalarına etkisi, A.Ü. Eğitim Bilimleri Fakültesi Yayınları.

Kuzgun, Y., Sevim, S. A., ve Hamamc1, Z. (2016). Mesleki doyum ölçeğinin geliştirilmesi. Türk Psikolojik Danışma ve Rehberlik Dergisi, 2(11), 14-18.

Maslach, C. ve Zimbardo, P. G. (1982), Burnout - The Cost of Caring, PrenticeHall, Inc., Englewood Cliffs, New Jersey.

Maslach, C., Schaufeli, W. B. ve Leiter, M, P. (2001), Job Burnout, Annual Review of Psychology, Volume: 52, 397-422.

Mersin, Y. (2007). Din görevlilerinde mesleki doyum. Yayımlanmamış Yüksek Lisans Tezi, Selçuk Üniversitesi, Sosyal Bilimler Enstitüsü, , Konya.

Özer, M., ve Karabulut, Ö.Ö. (2003), Yaşlılarda yaşam doyumu. Geriatri, 6(2), $72-74$.

Recepoğlu, E., ve Tümlü, G. Ü. (2015). Üniversite akademik personelinin mesleki ve yaşam doyumları arasındaki ilişkinin incelenmesi. Kastamonu Education Journal, 23(4), 1851-1868. 
Sucuoğlu, B. ve Kuloplu, N. (1996). Özürlü çocuklarda çalışan öğretmenlerde tükenmişliğin değerlendirilmesi. Türk Psikoloji Dergisi. 10(36), 44-60.

Taşğın, Ö. (2004). Gençlik ve Spor Genel Müdürlü̆̆̈̈ merkez ve taşra örgütü yöneticilerinin tükenmişlik düzeylerinin iş doyum düzeylerine etkisi. Yayınlanmamış Doktora Tezi, Konya: Selçuk Üniversitesi Sosyal Bilimler Enstitüsü.

Tekin, Ç., Bozkır, Ç., Sazak, Y., ve Özer, A. (2014). Malatya il merkezinde çalışan aile hekimleri ile aile sağlığı elemanlarının, aile hekimliği uygulaması hakkındaki görüşleri, iş doyumu düzeyleri ve etkileyen faktörler. Firat Tip Dergisi , 19(3), 135-139.

Tunaboylu, M. (2015). Ilkokul ve ortaokul öğretmenlerinin mesleki tükenmişlik düzeyleri: İzmir ili torbalı ilçesi örneği. Yayımlanmamış yüksek lisans tezi, Okan Üniversitesi

Uğur, A. (2015). Özel eğitim kurumlarında çalışan öğretmenler ile sinıföğretmenlerinin mesleki doyum düzeylerinin incelenmesi, Yayımlanmamış Doktora Tezi, Giresun Üniversitesi, Sosyal Bilimler Enstitüsü

Vızlı, C. (2005), Görme engelliler ilköğretim okullarında çalışan öğretmenlere normal ilköğretim okullarında çalışan öğretmenlerin tükenmişlik düzeylerinin karşılaştırılması Üsküdar ilçesi örneği, Yayınlanmamış Yüksek Lisans Tezi. Marmara Üniversitesi, Eğitim Bilimleri Enstitüsü, İstanbul.

Wright, T. A. ve Douglas, G. B. (1997), The contribution of burnout to work performance, Journal of Organizational Behavior, 18, 491-499.

Yiğit, R. (2013). Öğretmen adaylarının öznel iyi oluşu ile sosyal problem çözme becerileri arasındaki ilişkinin incelenmesi, İlköğretim Online, 12(2), 550-560.

\section{Kaynakça Bilgisi / Citation Information}

Çetinkaya, B., Gülaçtı, F. ve Çiftci, Z. (2019). Çalışanların mesleki tükenmişlik, mesleki doyum ve yaşam doyumunun incelenmesi. OPUS-Uluslararası Toplum Araştırmaları Dergisi, 14(20), 1475-1500. DOI: 10.26466/opus.613614 